\title{
Upper eyelid entropion and dry eye in cicatricial trachoma without trichiasis
}

\author{
Entrópio de pálpebra superior e olho seco no tracoma cicatricial sem triquíase
}

Abrahão lucena ${ }^{1}$, Patricia Mitiko Santello Akaishi ${ }^{1}$, Maria de Lourdes Veronesi Rodrigues ${ }^{2}$, Antonio Augusto Velasco e Cruz ${ }^{2}$

\begin{abstract}
Purpose: to evaluate the position of the upper eyelid margin and eye surface status in cicatricial trachoma without trichiasis (TS).

Methods: Slit-lamp biomicroscopy was employed to evaluate the location of the upper lid mucocutaneous transition of 156 eyes of 78 patients with trichiasis and of 130 eyes of 65 control subjects. For each eye the position of the upper lid mucocutaneous junction was graded with respect to the line of meibomian gland orifices into 3 categories: a) anterior, b) at the line, and c) posterior to the line. Ocular surface dye staining with lissamine green was performed in all eyes. All participants answered a questionnaire with queries on the presence and intensity of dry eye symptoms. Results: In the eyes with trichiasis the location of the mucocutaneous transition was posterior to the meibomian gland line in 55 (35.3\%), at the line in $77(49.4 \%)$ and anterior to the line in only 24 (15.4\%). In the control group these figures were: 5 (3.8\%); $42(42 \%)$ and $83(63.8 \%)$. Lissamine staining and dry eye symptoms were also associated with trichiasis.

Conclusion: Different degrees of upper lid entropion are already present in cicatricial trachoma even in the absence of trichiasis. Trichiasis is associated with lissamine green staining and dry eye symptoms. Conjunctivalization of the upper lid margin may play a role in the development of trachomatous dry eye.
\end{abstract}

Keywords: Trachoma; Cicatrix; Dry eye syndromes; Entropion; Eyelids; Lissamine green dyes/diagnostic use; Questionnaires

\section{RESUMO}

Objetivos: Avaliar a posição da margem palpebral superior e a superficie ocular no tracoma cicatricial sem triquíase (TS).

Métodos: A localização da transição mucocutânea da pálpebra superior foi avaliada com lâmpada de fenda em 156 olhos de 78 pacientes com triquíase e de 130 olhos de 65 controles. A posição da transição mucocutânea foi classificada em relação à linha das glândulas de Meibômio em três categorias: a) anterior, b) sobre a linha e c) posterior a linha. A superfície ocular de todos os olhos foi avaliada com verde de lissamina. Todos os participantes responderam ao questionário sobre a presença e intensidade dos sintomas relacionados ao olho seco.

Resultados: Nos ol hos com triquíase a localização da transição mucocutânea foi posterior à linha das glândulas de Meibômio em 55 (35,3\%), sobre a linha em 77 (49,4\%) e anterior à linha em somente $24(15,4 \%)$. No grupo controle essa distribuição foi 5 (3,8\%); $42(42 \%)$ e 83 (63,8\%). A positividade ao corante de lissamina e sintomas de olho seco também foram associados à triquíase.

Conclusão: Diferentes graus de entrópio de pálpebra superior estão presentes no tracoma cicatricial mesmo na ausência de triquíase. Triquíase está associada à positividade ao corante verde lissamine e sintomas de ol ho seco. A conjuntivalização da margem palpebral pode ser um fator no desenvolvimento do ol ho seco tracomatoso.

Descritores: Tracoma; Cicatriz; Síndromes do olho seco; Entrópio; Pálpebras; Corantes verdes de lissamina/uso diagnóstico; Questionários

\section{INTRODUCTION}

The main sequence of the pathologic events that provoke vision loss in trachoma is well known. Repeated infection of the eye with Chlamydia trachomatis usually occurs in children and leads to the inflammatory stage of the disease, which is characterized by lymphoid follicles or diffuse inflammation of the upper tarsal conjunctiva. The active forms of trachoma, if not controlled, are followed in adulthood by cicatricial changes on the tarsal plate of the upper eyelid. Loss of vision results from chronic corneal abrasion caused by upper eyelid entropion and trichiasis ${ }^{(1)}$.

Since the eighties, when the World Health Organization (WHO) successfully establish a simple and reliable system of trachoma classification for population-based surveys, the cicatricial trachomatous effects on the upper eyelid have been divided into two categories: trachomatous scarring (TS) and trachomatous trichiasis (TT). TS is defined by the presence of white lines or bands of cicatrization on the upper tarsal conjunctiva. The designation TT is used when there is at least one eyelash rubbing the ocular surface ${ }^{(2)}$.

In cases of TT it seems clear that the eyelid margin is rotated inwards; in other words, there is upper eyelid entropion. In TS, the position of the upper eyelid margin has not been defined. In this article we report the results of a biomicroscopic analysis of the lid margin position of a large series of patients with TS and analyzed the effect of lid position on their ocular surface status.

\section{METHODS}

\section{Patients}

The sample derived from a trachoma survey conducted in the village of Simão, state of Ceará, Brazil. This village is located in one of the first regions in Brazil where trachoma was diagnosed as an endemic health problem. There were 78 (156 eyes) patients with TS
Funding: No specific financial support was available for this study.

Disclosure of potential conflicts of interest: A.Lucena, None; P.M.S.Akaishi, None; M.L.V.Rodrigues, None; A.A.V.Cruz, None.

Correspondence address: Antonio Augusto Velasco Cruz. Departamento de Oftalmologia, Otorrinolaringologia e Cirurgia de Cabeça e Pescoço. Hospital das Clínicas-Campus, Av. Bandeirantes, 3.900 - Ribeirão Preto (SP) - 14049-900 - Brazil - E-mail: aavecruz@fmrp.usp.br 
(46 females, 32 males ranging in age from 30 to 83 , mean $=60.5 \pm$ $11.2 \mathrm{sd}$ years). A group of 65 subjects (41 females, 24 males ranging in age from 39 to 82 , mean $=53.4 \pm 10.5$ sd years) from the same area without any clinical evidence of trachomatous signs were also examined as controls.

\section{Procedures}

First, all participants answered a questionnaire with queries on the presence and intensity of dry eye symptoms. Seven symptoms (visual changes, burning, foreign body sensation, light sensitivity, visual changes, and eye irritation in the morning or towards the night) were graded according a 4-level ordinal scale $(0=$ never, $1=$ mild, $2=$ moderate, $3=$ severe). Based on the sum of the scores, subjects were classified as having no (0-2), mild (3-7), moderate (8-14) and intense (15-21) symptoms of dry eye.

Two experienced ophthalmologists with oculoplastic training performed a comprehensive biomicroscopic analysis of the upper lid margin and ocular surface in all subjects. The lid mucocutaneous junction was identified and its position graded with respect to the line of meibomian gland orifices into 3 categories: a) anterior, b) at the line, and c) posterior to the line (Figure 1). Ocular surface dye staining with lissamine green (LG) was then performed. One drop of LG was instilled on the inferior fornix without any previous anesthetic drops. Any staining area on the nasal or temporal bulbar conjunctiva was recorded as positive. Conjunctival areas with any abnormalities such as pterygium or pingueculas were excluded.

\section{Statistical analysis}

The $\mathrm{Z}$ test for two proportions was used to compare the position of the mucocutaneous lid transition in both groups. Contingency tables and the Fisher exact test were employed to determine the association between the position of the mucocutaneous junction, the positivity of green or fluorescein staining and the intensity of dry eye symptoms.

We certified that all applicable institutional and governmental regulations concerning the ethical use of human volunteers were followed during this research.

\section{RESULTS}

The position of the mucocutaneous transition was significantly different between the groups (Table 1). Of the 156 eyes with TS, the transition was posterior to the meibomian gland line in 55 (35.3\%), at the line in 77 (49.4\%) and anterior to the line in only 24 (15.4\%). In the 130 eyes of the control group these figures were: 5 (3.8\%); 42 (42\%) and 83 (63.8\%). The Fisher exact test revealed that a mucocutaneous line located at or posterior to the mucocutaneous meibomian gland line is strongly associated with TS ( $p<0.0001$; odds ratio $9.7(95 \% \mathrm{Cl}$ 5.53 - 17.06)

Lissamine staining (Table 2) was positive in $22.4 \%$ of the eyes with TS and in $7.7 \%$ of the controls. The association between lissamine staining and TS was also highly significantly $(p=0.0006$; odds ratio = 3.47, (95\% Cl 1.64 - 7.33).

Only two subjects with TS and one control had severe dry eye symptoms (Table 3). When the symptoms were grouped (none + mild versus moderate + severe) the association between dry eye complaints and TS was just significant $(p=0.05$; odds ratio $=1.05-4.58$ ).

\section{DISCUSSION}

Conjunctival scarring plays a pivotal role in the lid changes induced by trachoma. Repeated bacterial infections ${ }^{(3)}$ and immune factors ${ }^{(4)}$ induce a subepithelial fibrous membrane adherent to the tarsal plate even in the absence of Chamydia trachomatis ${ }^{(5)}$. Confocal
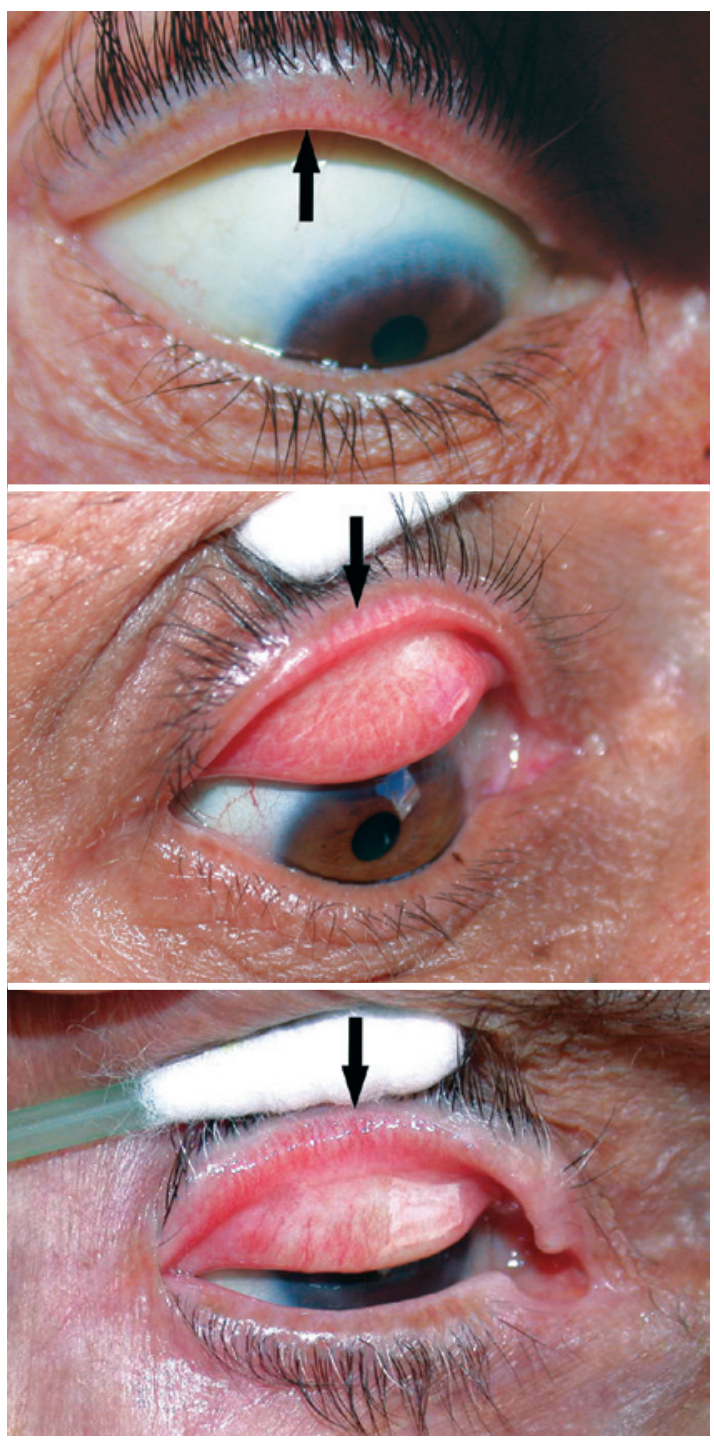

Figure 1. Position of the upper lid mucocutaneous junction (black arrow) relative to the line of the orifices of the Meibomian glands. Top=anterior the line; middle= over the line; bottom= posterior the line.

Table 1. Lid margin position in controls and patients with cicatricial trachoma

\begin{tabular}{|c|c|c|}
\hline \multirow{2}{*}{$\begin{array}{l}\text { Position of the mucocutaneous } \\
\text { transition relative to the } \\
\text { meibomian glands orifices line }\end{array}$} & \multicolumn{2}{|c|}{ Groups n/(\%), $95 \mathrm{Cl}$} \\
\hline & Controls & TS \\
\hline Anterior the line & 83/(63.8\%), $55.3-71.6$ & $24 /(15.4 \%), 10.5-21.9)$ \\
\hline At the line & $42 /(32.3 \%), 24.9-40.8$ & $77 /(49.4 \%), 41.6-57.1)$ \\
\hline Posterior the line & $5 /(3.8 \%), 1.4-8.9$ & $55 /(35.3 \%), 26.2-45.5)$ \\
\hline
\end{tabular}

Table 2. Ocular surface staining in cicatricial trachoma

\begin{tabular}{|c|c|c|}
\hline \multirow[b]{2}{*}{ Lissamine green staining } & \multicolumn{2}{|c|}{ Groups n/(\%), $95 \mathrm{Cl}$} \\
\hline & Controls & TS \\
\hline Negative & 120/(92.3\%), 86.3 - 95.9 & $121 /(77.6 \%), 70.4-83.4$ \\
\hline Positive & $10 /(7.7 \%), 4.1-13.7$ & $35 /(22.4 \%), 16.6-29.6$ \\
\hline
\end{tabular}


Table 3. Dry eye symptoms

\begin{tabular}{lcc}
\hline \multirow{2}{*}{ Dry eye symptoms } & \multicolumn{2}{c}{ Groups n/(\%), 95 Cl } \\
\cline { 2 - 3 } None + Mild & $50 /(76.9 \%), 65.2-85.6$ & $47 /(60.3 \%), 49.1-70.4)$ \\
Moderate + Severe & $15 /(23.1 \%), 14.4-34.7$ & $31 /(39.7 \%), 29.6-50.8)$ \\
\hline
\end{tabular}

microscopy has revealed that there is a wide spectrum of subepithelial cicatricial changes ranging from fine strands of amorphous tissue to broad bands of connective tissue ${ }^{(6)}$.

It seems natural to admit that lid margin rotation is correlated with the degree of tarsal plate subepithelial fibrosis. As noticed by Sarkies in 1965 ${ }^{(7)}$, upper lid entropion is not a sudden event and different degrees of margin inward rotation exist in trachoma. The position of the conjunctival edge relative to the meibomian gland line provides a useful clinical landmark to assess subtle degrees of entropion ${ }^{(7)}$. Our data show that there is a significant association between TS and conjunctival staining with the vital dye lissamine green. We think that upper lid margin rotation is a factor in the development of the so-called trachomatous dry eye ${ }^{(7)}$. In our sample, only $15.4 \%$ of the eyes with TS had the conjunctival edge posterior to the meibomian gland line. When mucosal tissue overlies the meibomian orifices, a process known as conjunctivalization of the lid margin ${ }^{(9)}$, meibomian gland secretion is impaired and the tear film lipid layer is expected to decrease, leading to evaporating dry eye ${ }^{(10)}$. The WHO system of trachoma grading does not assess the degree of lid margin rotation.

\section{CONCLUSION}

From an epidemiological point of view, it is natural to consider only the presence of trichiasis as an indication for surgery. However, even in the absence of any lashes touching the eye, the relationship between lid margin and the ocular surface is often abnormal in TS. Although severe dry eye was not common in our study, $22.4 \%$ of the eyes with TS were positive for lissamine staining. We think that, on an individual basis, lid surgery should not be denied to patients with TS who have complaints of irritation or dry eye.

\section{REFERENCES}

1. Dawson CR. Pathogenesis and control of blinding trachoma. In: Tasman W, Jaeger ER editors. Duane's clinical ophthalmology. Philadelphia: Lippincott-Raven; 1995. p.1-11.

2. Thylefors B, Dawson CR, Jones BR, West SK, Taylor HR. A simple system for assessment of trachoma and its complications. Bull World Health Organ. 1987;65(4):477-83.

3. Hu VH, Massae P, Weiss HA, Chevallier C, Onyango JJ, Afwamba IA, et al. Bacterial infection in scarring trachoma. Invest Ophthalmol Vis Sci 2011;52(5):2181-6.

4. Burt MJ, Rajak SN, Bauer J, Weiss HA, Tolbert SB, Shoo A, et al. Conjunctival transcriptome in scarring trachoma. Infect Immun. 2001;79(1):499-511.

5. Al-Rajhi AA, Hidayat A, Nasr A, Al-Faran M. The histopathology and the mechanism of entropion in patients with trachoma. Ophthalmology 1993;100(9):1293-6.

6. Hu VH, Massae P, Weiss HA, Cree IA, Courtright P, Mabey DC, et al. In vivo confocal microscopy of trachoma in relation to normal tarsal conjunctiva. Ophthalmology. 2011;118(4):747-54.

7. Sarkies JW. Early changes in margin of upper eyelid in entropion complicating trachoma. Br J Ophthalmol. 1965;49(10):538-41.

8. Guzey M, Ozardali I, Kilic A, Basar E, Dogan Z, Satici A, Karadede S. The treatment of severe trachomatous dry eye with canalicular silicone plugs. Eye. 2001;15(Pt 3):297-303.

9. Kemp EG, Collin JR. Surgical management of upper lid entropion. Br J Ophthalmol. 186;70(8):575-9.

10. Bron AJ, Tiffany JM. The contribution of meibomian disease to dry eye. Ocul Surf. 2004;2(2):149-65. 